\title{
Proceeding
}

Supplementary Issue: Winter Conferences of Sports Science. Costa Blanca Sports Science Events, 22-23 March 2021. Alicante, Spain.

\section{Methods of accounting the cycling intensity: Advantages and disadvantages}

\author{
N.S. KIREEVA $\triangle$, D.Y. SOBOLEV, E. V. SLEPENKOVA \\ Entrepreneurship and Logistics Department, Plekhanov Russian University of Economics, Moscow, Russia
}

\begin{abstract}
In the paper, manual and automated methods as to accounting for traffic intensity are considered. They are evaluated from the point of view of their possible use under various conditions: traffic intensity, types and tasks of measurements, and the necessarily detailed information. Based on a study of the intensity of cycling in Moscow, it was concluded that in a metropolis with an insufficiently developed bicycle infrastructure, manual metering will be the best method of accounting. In addition to the manual method, mobile app data and bike rental statistics should be used.

Keywords: Bicycle traffic monitoring; Urban infrastructure; Bicycle traffic; Bicycle rental; Non-motorized vehicles.

\section{Cite this article as:}

Kireeva, N.S., Sobolev, D.Y., \& Slepenkova, E.V. (2021). Methods of accounting the cycling intensity: Advantages and disadvantages. Journal of Human Sport and Exercise, 16(3proc), S856-S863. https://doi.org/10.14198//hse.2021.16.Proc3.02
\end{abstract}

Corresponding author. Entrepreneurship and Logistics Department, Plekhanov Russian University of Economics, Moscow, Russia. https://orcid.org/0000-0003-1008-7026

E-mail: kudryavtseva.natalyb@mail.ru

Abstract submitted to: Autumn Conferences of Sports Science. Costa Blanca Sports Science Events, 18-19 December 2020. Alicante, Spain.

JOURNAL OF HUMAN SPORT \& EXERCISE ISSN 1988-5202.

(c) Faculty of Education. University of Alicante.

doi:10.14198/jhse.2021.16.Proc3.02

S856 | 2021| Proc3 | VOLUME 16

(c) 2021 University of Alicante 


\section{INTRODUCTION}

The quality of life in cities largely depends on the effectiveness of the transport system functioning. (Maksimova, Danilov Kazantseva, 2017). Many large cities, in particular Moscow, are growing rapidly, which requires accelerated expansion of the transport infrastructure, taking into account the interests of not only car owners, but also pedestrians and users of various non-motorized vehicles (NMVs).

Despite the fact that now automobile transport is most in demand inside cities, (Bezuglaya, 2013) urban transport policy should include measures to develop bicycle transport ( Borovsky , 2017). This is due to the fact that an increase in the number of cars worsens the environmental situation, and increases accident rate, the number of traffic jams and noise levels.

In many cities around the world, much attention has been paid for a long time to the development of cycling (http://www.nycdotplan.nyc/PDF/Strategic-plan-2016).

Cycling infrastructure development projects require a preliminary assessment of the intensity of existing cycling, identifying cyclist needs, setting goals, and tracking the performance of these goals.

In this regard, the urgent task is to create a system for monitoring the intensity of bicycle traffic (Kireeva, et al. 2020). In turn, the monitoring system is based on the count of road users using a bicycle as a vehicle.

We conducted a comparative study of accounting tools and methods to identify the most appropriate of them for assessing the intensity and subsequent continuous monitoring of cycling in large cities.

\section{MATERIALS AND METHODS}

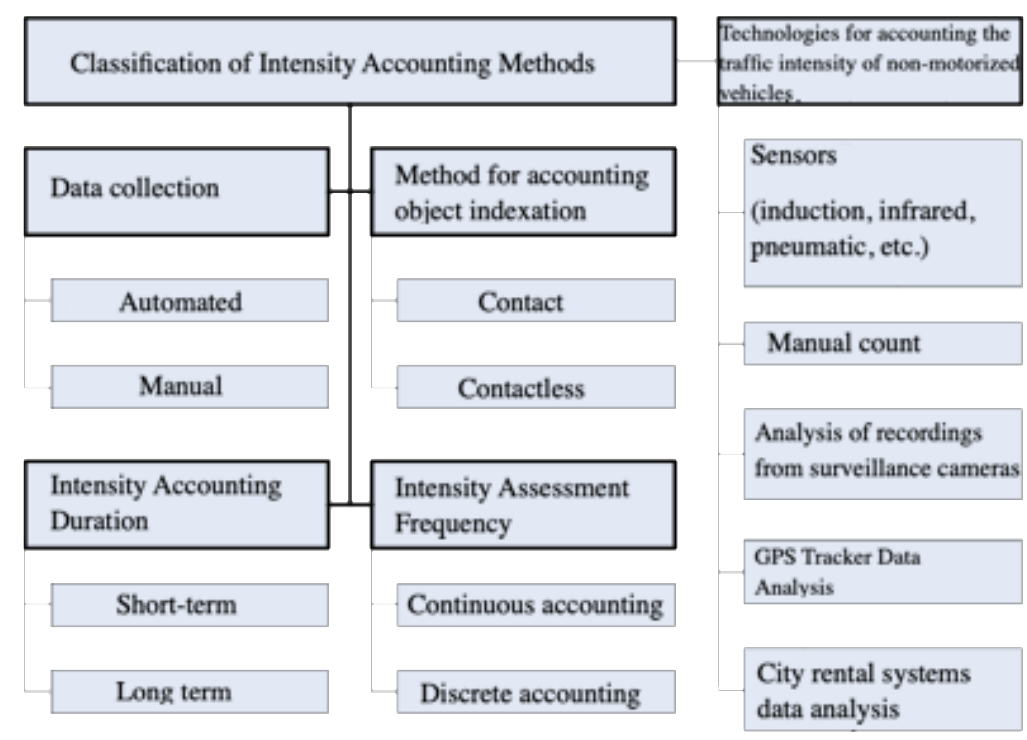

Figure 1. Classification of intensity accounting methods Source: compiled by the authors based on (Evseeva, 2017).

Based on the classification of methods, we took the most common methods for monitoring bicycle traffic in the city (Evseeva, 2017): 
1. Manual counting;

2. Counting using sensors;

3. Analysis of recordings made by CCTV cameras;

4. Analysis of GPS tracks;

5. Data analysis of urban bike rental systems.

Figure 1 presents a classification of methods for accounting for intensity.

Based on this classification, we evaluated the accounting technologies in relation to the objectives of our study (assessing the intensity and monitoring of cycling). In addition to technical features, we took into account the following factors: the ability to take into account various parameters, the cost of the accounting process, the quality of the data received, and others.

\section{RESULTS AND DISCUSSION}

\section{Manual data collection method}

The manual method is one of the main as to accounting for the intensity of movement of cyclists. Measurements are carried out both using mechanical counters, and without them (manual field observations). Using the manual method, we can get data not only about traffic fluctuations, but also information about other indicators. For example, about the gender and age of cyclists, their protective equipment (helmets), the use of mobile devices during a trip. Accounting is carried out at the same points at different times of the day.

For example, a manual method is used to record the intensity of cycling in Australia and Canada. Volunteers are involved in the measurements.

In 2017-2018 in Moscow, RUE named after G.V. Plekhanov conducted a study on the intensity of cycling and the movement of other non-motorized vehicles. In this study, the accounting was performed using date from five metering points by street types using the manual visual method. A limitation for this method of accounting was the possibility of the absence of a maximum point in the measurement intervals for short-term measurements.

In addition to using paper forms and mechanical counters, the results can be captured in special mobile counter applications, for example, Counterpoint. They provide the most accurate results. A mechanical clicker counter may also be used. To study the intensity of bicycle flows, it is possible to use "visitor counters" which are used, as a rule, for conducting marketing research in shopping centres, for example, SM Counters. However, when using them, errors arise with the distinction between cyclists and pedestrians. Therefore, given the low bicycle traffic, budget and time constraints, we used special forms to conduct the research.

\section{Automated data accounting methods}

Intensity metering methods are widely used using specialized sensors that allow on-line mode to record cyclists with high accuracy. Depending on the technology used, there are pneumatic, piezoelectric, fibre optic, induction, infrared, laser, magnetic, etc. Their comparative analysis is presented in Table 1.

One of the findings of monitoring the use of bicycles in Scotland (www.cycling.scot/mediaLibrary/other/english/1113) in 2016 was the mandatory use of automatic intensity meters in the main areas of cycling to record its dynamics. 
In our study, in addition to manual counting, video clips provided by the Department of Transport and the Development of Road Transport Infrastructure of Moscow were processed. Video processing was also carried out manually. The disadvantage of this method was that the cameras (12 points) were installed at sufficiently high heights, so they did not allow revealing the age and sex characteristics of cyclists and their protective equipment. In the future, it would be necessary to consider the possibility of installing CCTV cameras at a height that provides the possibility of recognizing cyclists and users of other NMVs in the flow of pedestrians and cars.

The requirement for long-term and continuous measurements with high quality data causes increasing in the cost of measurements. Manual measurements are not advisable for long continuous measurements but are indispensable in assessing the characteristics or attributes of cyclists. A compromise solution can be selected based on the table 1 and table 2.

Table 1. Technologies intended for accounting for traffic intensity of non-motorized vehicles.

\begin{tabular}{|c|c|c|c|}
\hline Technology & Typical application & Strengths & Limitations \\
\hline Induction loops & $\begin{array}{l}\text { Continuous } \\
\text { measurements } \\
\text { (installation under the } \\
\text { road surface or in cuts) } \\
\text { Short-term } \\
\text { measurements (tape on } \\
\text { the coating) } \\
\text { Bicycles only }\end{array}$ & $\begin{array}{l}\text { Accurate data with proper } \\
\text { installation and } \\
\text { configuration of equipment }\end{array}$ & $\begin{array}{l}\text { Only cyclists can be counted. } \\
\text { Installation in the pavement requires } \\
\text { the use of professional equipment to } \\
\text { create cuts or install loops before } \\
\text { applying the pavement. } \\
\text { There is a possibility of erroneous } \\
\text { calculations when groups of cyclists } \\
\text { make their travels. } \\
\text { Possibility of interference with other } \\
\text { electrical equipment }\end{array}$ \\
\hline $\begin{array}{l}\text { Microwave } \\
\text { sensors }\end{array}$ & $\begin{array}{l}\text { Short- or long-term } \\
\text { measurements } \\
\text { Cyclists and pedestrians } \\
\text { in aggregate }\end{array}$ & $\begin{array}{l}\text { Ability to count cyclists on } \\
\text { dedicated bike lanes or } \\
\text { lanes }\end{array}$ & $\begin{array}{l}\text { Not enough offers in the market of } \\
\text { commercial devices. } \\
\text { Range Limit }\end{array}$ \\
\hline $\begin{array}{l}\text { Video Capture - } \\
\text { Auto Analysis }\end{array}$ & $\begin{array}{l}\text { Short- or long-term } \\
\text { measurements } \\
\text { Cyclists and pedestrians } \\
\text { separately }\end{array}$ & $\begin{array}{l}\text { Possibility of greater } \\
\text { accuracy of calculations in } \\
\text { areas of heavy traffic } \\
\text { compared to manual } \\
\text { calculation }\end{array}$ & $\begin{array}{l}\text { Usually more expensive for a } \\
\text { separate installation of equipment } \\
\text { Recognition algorithms require } \\
\text { further development and } \\
\text { improvement }\end{array}$ \\
\hline $\begin{array}{l}\text { Active IR } \\
\text { Sensor }\end{array}$ & $\begin{array}{l}\text { Short- or long-term } \\
\text { measurements } \\
\text { Cyclists and pedestrians } \\
\text { in aggregate }\end{array}$ & $\begin{array}{l}\text { Relatively portable } \\
\text { technology } \\
\text { Low-observable and not } \\
\text { attracting attention }\end{array}$ & $\begin{array}{l}\text { This technology cannot distinguish } \\
\text { between pedestrians and cyclists, } \\
\text { except when combined with another } \\
\text { cyclist recognition technology. } \\
\text { Very difficult to use on bike lanes or } \\
\text { combined lanes. } \\
\text { The possibility of erroneous } \\
\text { calculations when groups of cyclists } \\
\text { make their travels }\end{array}$ \\
\hline $\begin{array}{l}\text { Passive IR } \\
\text { Sensor }\end{array}$ & $\begin{array}{l}\text { Short- or long-term } \\
\text { measurements } \\
\text { Cyclists and pedestrians } \\
\text { separately }\end{array}$ & $\begin{array}{l}\text { Portable with easy } \\
\text { installation } \\
\text { Low-observable and not } \\
\text { attracting attention }\end{array}$ & $\begin{array}{l}\text { It cannot distinguish between } \\
\text { pedestrians and cyclists, except } \\
\text { when combined with another cyclist } \\
\text { recognition technology. } \\
\text { It is very difficult to use on bike } \\
\text { lanes or combined lanes; it requires }\end{array}$ \\
\hline
\end{tabular}




\begin{tabular}{|c|c|c|c|}
\hline & & & $\begin{array}{l}\text { careful installation and configuration } \\
\text { of equipment. } \\
\text { At high ambient temperatures } \\
\text { (about }+30^{\circ} \mathrm{C} \text { ) it can produce more } \\
\text { false operations. } \\
\text { There is a possibility of erroneous } \\
\text { calculations when groups of cyclists } \\
\text { make their travels. } \\
\text { Direct sunlight on the sensor may } \\
\text { cause erroneous triggering. }\end{array}$ \\
\hline $\begin{array}{l}\text { Pneumatic } \\
\text { tubes }\end{array}$ & $\begin{array}{l}\text { Short term } \\
\text { measurements } \\
\text { Cyclists only }\end{array}$ & $\begin{array}{l}\text { Relatively portable, low-cost } \\
\text { technology } \\
\text { Already installed equipment } \\
\text { can be used to count both } \\
\text { motorized vehicles and non- } \\
\text { motorized vehicles }\end{array}$ & $\begin{array}{l}\text { Only cyclists can be counted. } \\
\text { One can trip over a tube. } \\
\text { There is a greater risk of vandalism } \\
\text { and equipment damage. } \\
\text { The method cannot be used in } \\
\text { winter conditions. }\end{array}$ \\
\hline $\begin{array}{l}\text { Video Capture - } \\
\text { Manual } \\
\text { Analysis }\end{array}$ & $\begin{array}{l}\text { Short term } \\
\text { measurements } \\
\text { Cyclists and pedestrians } \\
\text { separately }\end{array}$ & $\begin{array}{l}\text { Lower costs when using } \\
\text { already installed } \\
\text { camcorders }\end{array}$ & $\begin{array}{l}\text { Limited to short term use. } \\
\text { Manual video analysis is a very } \\
\text { laborious process. }\end{array}$ \\
\hline Manual count & $\begin{array}{l}\text { Short term } \\
\text { measurements } \\
\text { Cyclists and pedestrians } \\
\text { separately }\end{array}$ & $\begin{array}{l}\text { It can be used to confirm } \\
\text { data obtained by automatic } \\
\text { methods. }\end{array}$ & $\begin{array}{l}\text { Convenient for short-term } \\
\text { measurements; there should be } \\
\text { high labour costs in the case of } \\
\text { long-term measurements. }\end{array}$ \\
\hline
\end{tabular}

Table 2. Principles of choosing technologies for accounting for traffic intensity of non-motorized vehicles.

\begin{tabular}{|c|c|c|c|c|c|}
\hline $\begin{array}{l}\text { Intensity } \\
\text { accounting } \\
\text { duration }\end{array}$ & Technology & Cyclists & Pedestrians & $\begin{array}{l}\text { Pedestrians } \\
\text { and cyclists in } \\
\text { aggregate }\end{array}$ & $\begin{array}{l}\text { Pedestrians } \\
\text { and cyclists } \\
\text { separately }\end{array}$ \\
\hline \multirow{4}{*}{$\begin{array}{l}\text { Constant intensity } \\
\text { accounting }\end{array}$} & Induction loops & & & & \\
\hline & Magnetometer & & & & \\
\hline & Pressure meter & & & & \\
\hline & Microwave sensor & & & & \\
\hline $\begin{array}{l}\text { Continuous } \\
\text { Intensity } \\
\text { accounting }\end{array}$ & $\begin{array}{l}\text { Automatic video } \\
\text { recording system }\end{array}$ & & & & \\
\hline \multirow[t]{5}{*}{$\begin{array}{l}\text { Short term } \\
\text { measurements }\end{array}$} & $\begin{array}{l}\text { IR sensor (active / } \\
\text { passive) }\end{array}$ & & & & \\
\hline & Pneumatic tubes & & & & \\
\hline & $\begin{array}{l}\text { Combined } \\
\text { technology }\end{array}$ & & & & \\
\hline & $\begin{array}{l}\text { Manual video } \\
\text { recording }\end{array}$ & & & & \\
\hline & Observers & & & & \\
\hline
\end{tabular}

Note: Dark blue = High efficiency; Light blue = Average efficiency; White = Low efficiency. 
Mobile applications (GPS data)

A modern tool for counting cyclists is the analysis of GPS data on their movements. Such data is called tracks and is collected by specialized applications for smartphones (Strava, Cyclemeter, etc.), fitness trackers and smart watches, as well as transport navigators (Citymapper, Google Maps, Yandex, etc.). Since the analysis of GPS data allows users to identify the most popular routes, it is a promising tool when planning a new infrastructure. The results of studies on the use of GPS data are presented in the works by G. Romanillos, M.Z. Austwick, D. Etema, J. De Kruijf ( Romanillos, et al. 2015).

The GPS data advantages are: (1) ease of connection; the use of large computer networks for data analysis; (2) assessment of a large number of users; (3) routed routes and their intensity; (4) high radius of coverage of research on the territory, etc.

The main disadvantages limiting the use of GPS data are: (1) a small number of Russian developments; (2) not all systems analyse data, including foreign ones; (3) the inability to assess the additional characteristics of users and the state of the infrastructure. Comparative characteristics of GPS data measurement instruments are presented in Table 3.

Table 3 Characteristics of GPS data measurement instruments.

\begin{tabular}{|c|c|c|c|c|c|}
\hline Specifications & Strava & My tracks & Endomondo & Aerobia & Runstatic \\
\hline Number of users & $\begin{array}{l}\text { + Largest } \\
\text { number }\end{array}$ & $\begin{array}{l}\text { - The social } \\
\text { component is } \\
\text { not developed }\end{array}$ & $\begin{array}{l}\text { + Sufficient number } \\
\text { of users }\end{array}$ & $\begin{array}{l}\text { - User number is } \\
\text { poorly } \\
\text { accounted }\end{array}$ & $\begin{array}{l}\text { - Poorly } \\
\text { Russified }\end{array}$ \\
\hline $\begin{array}{l}\text { Ease of } \\
\text { connection }\end{array}$ & $\begin{array}{l}+ \text { Most } \\
\text { advanced }\end{array}$ & $\begin{array}{l}\text { + Convenient } \\
\text { system }\end{array}$ & $\begin{array}{l}\text { - Complicated } \\
\text { connection }\end{array}$ & $\begin{array}{l}\text { + Fast } \\
\text { connection and } \\
\text { convenient } \\
\text { design }\end{array}$ & $\begin{array}{l}\text { + Convenient } \\
\text { connection }\end{array}$ \\
\hline $\begin{array}{l}\text { Convenience of } \\
\text { functionality }\end{array}$ & $\begin{array}{l}+ \text { A user can set } \\
\text { the rhythm, } \\
\text { route; runs are } \\
\text { automatically } \\
\text { connected to } \\
\text { any GPS } \\
\text { system }\end{array}$ & $\begin{array}{l}\text { + Will record } \\
\text { the path and } \\
\text { save it on the } \\
\text { Google server }\end{array}$ & $\begin{array}{l}\text { + Can track routes, } \\
\text { make single and } \\
\text { group routes; } \\
\text { connect the warning } \\
\text { system "the number } \\
\text { of kilometres } \\
\text { travelled for a } \\
\text { certain period" }\end{array}$ & $\begin{array}{l}\text { + Russian } \\
\text { development; } \\
\text { route planning }\end{array}$ & $\begin{array}{l}\text { - There are } \\
\text { few routes in } \\
\text { Russia; }\end{array}$ \\
\hline
\end{tabular}

For megacities, it is advisable to develop a special application that allows us to keep track of the movements of cyclists along the streets of the city. This application is installed on smartphones of bicycle users and must have access to GPS data, information about the current weather and its forecast values, the ability to start and stop manually, as well as automatically record movements on a bicycle (the criterion is the speed of movement with geolocation and bike path alignment).

For Moscow, it is important to integrate information support for cyclists (the availability of nearby parking lots, bike rental systems, service centres, etc., types of bike paths when moving along a laid route, etc.) with information for moving around the city using public transport.

The positioning of this application can be carried out among users seeking a healthy lifestyle, as well as among citizens who are not indifferent to the development of their hometown, for example, users of the Active 
Citizen application. The incentive to install such an application may be the accumulation of bonuses on the Troika city transport card for subsequent payment of bicycle rental or use of public transport routes.

In addition to the basic navigation functions, this application should be able to measure:

- Real routes of users' movement;

- Speed of movement;

- The duration and frequency of stops along the route;

- The duration of the bike ride;

- Weather conditions (in the context of temperature, precipitation, wind);

- Elevation changes along the route;

- NMV identification (bicycle, scooter, etc.);

- Identification of NMV ownership (own, rental).

Establishing dependencies between these data will allow designing a more efficient bicycle infrastructure in Moscow.

Data of urban bike rental systems

If there is a rental system in the cities, the traffic intensity of cyclists can be monitored according to the data available to companies engaged in bicycle rental activities. A limitation in this case is the need to observe commercial secrets and the legal possibility of using personal data of users.

\section{CONCLUSION}

A study and analysis of foreign practices allows us to conclude that in a metropolis with an underdeveloped bicycle infrastructure, the manual method is optimal for taking into account the intensity of cycling. A limitation of this method of accounting is the possibility of absence of a maximum point in the measurement intervals for short-term measurements. Among the technical means used with this method of accounting, special mobile applications provide the greatest accuracy.

The disadvantages of accounting methods for the intensity of cycling using specialized sensors do not allow their use in cities with an underdeveloped bicycle infrastructure.

The video recording method is also not effective enough since the current level of development of video camera data processing technologies does not allow cyclists and users of other NMVs to be recognized in the flow of pedestrians and cars. An analysis of the movement of cyclists in manual mode using recordings from video surveillance cameras does not make it possible to identify the age and sex characteristics of cyclists and the availability of protective equipment.

In addition to the manual method, statistics on bike rental and mobile applications should be used. This information allows scientists to visualize the most popular directions, duration, and intensity of movements within the area or between areas.

\section{DISCLOSURE STATEMENT}

The paper was prepared based on the results of 2017-2018 research work on the topic "Development of a methodology for assessing the cycling intensity and monitoring the use of bicycle infrastructure in the city of Moscow" (Agreement No. 157-DTiRDTI-S dated 20/12/2017). 


\section{REFERENCES}

Alvanides, S. Active transport: Why and where do people (not) walk or cycle? Journal of Transport \& Health December 2014 Vol. 1(4):211-213. https://doi.org/10.1016/i.jth.2014.11.002

Annual Bicycle Count [Digital source]: Free access http://www.calgary.ca/Transportation/TP/Pages/Cycling/Bike-Data.aspx (access date 10.01.2019).

Annual Cycling Monitoring Report [Digital source]: Free access https://www.cycling.scot/mediaLibrary/other/english/1113.pdf (access date 10.01.2019).

Bezuglaya E.V.(2013). Significance of social infrastructure for the socio-economic development of a region. Young scientist. No. 10. - P. 272-274.

Bicycle NetWork [Digital source]: Free access https://www.bicyclenetwork.com.au/ourservices/counts/super-tuesday/76 (access date 10.01.2019).

Borovsky O.N.(2017). The development of bicycle infrastructure as a solution to the transport and environmental problems of a modern city. Russian Journal of Entrepreneurship. - No. 15. - P. 22632276.

Evseeva A.I. (2017).Monitoring of bicycle traffic in a city. Public Administration. Electronic bulletin. - No. 64.

Kireeva, N., Zavialov, D., Saginova, O., \& Zavyalova, N. (2020). Indicator system for monitoring the development of urban bicycle transport infrastructure. Paper presented at the Journal of Physics: Conference Series, , 1425(1). https://doi.org/10.1088/1742-6596/1425/1/012070

Maksimova S.M., Danilov S.V., Kazantseva S.Yu(2017).. Determination of the social effect of the development of bicycle transport infrastructure of a megalopolis. Economics and Entrepreneurship. No. 11 (88) P. 584-588.

Plano de Mobilidade [Digital source]: Free access: https://www.prefeitura.sp.gov.br/cidade/secretarias/upload/chamadas/apresentacaoplanmob_1428956826.pdf (access date 10.01.2019).

Report January 2017. Bicycle and Pedestrian Data Collection Manual [Digital source]: Free access: http://www.dot.state.mn.us/research/reports/2017/201703.pdf (access date 10.01.2019).

Romanillos G., Austwick M.Z., Ettema D., De Kruijf J.(2015). Big Data and Cycling. Transport Reviews. № 36. - P. 1-20. https://doi.org/10.1080/01441647.2015.1084067

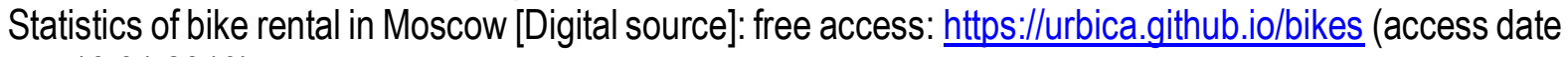
10.01.2019).

Strategic Plan [Digital source]: Free access: http://www.nycdotplan.nyc/PDF/Strategic-plan-2016.pdf (access date 10.01.2019).

Urban Mobility Plan [Digital source]: Free access: https://www.barcelona.cat/mobilitat/en/aboutus/urban-mobility-plan/fair-mobility (access date 10.01.2019).

Zavyalov D.V., Saginova O. V., Zavyalova N. B., Kireeva N. S. The concept and structure of monitoring bicycle transport infrastructure in Moscow. Russian Journal of Entrepreneurship. 2018. V.19. Number 4. P. 1273-1288.

\section{(9) $\odot \Theta \Theta$}

This work is licensed under a Attribution-NonCommercial-NoDerivatives 4.0 International (CC BY-NC-ND 4.0). 